\title{
Clapping In Seventh-Day Adventist Worship
}

\author{
Max H. Wauran \\ Faculty of Philosophy, Universitas Klabat \\ mwauran@unklab.ac.id
}

\begin{abstract}
Clapping is considered as a media of praise and thanks in Christian worship. Some give space to this practice while other reject it. This article tried to identify the biblical foundation of these ideas, and was carried out through the following phases: formulating the problem, preparing the title, and searching the related supporting materials in the library research and electronic facilities. The research focused on three main aspects: the clapping in the Bible, the Christian and practice of clapping in worship services, and clapping in Seventh-day Adventist Church. It is found that there is no Bible text and theological evidence which support the practice of clapping in the place of worship, in other words clapping in the church services is unbiblical, and for this reason clapping in Seventh-day Adventists worship services is not necessary. Instead of clapping, the use of amen is suggested in responding the message or musical presentation. Since clapping has become controversial issue in Adventist worship services, the church leaders need to instruct and guide the church members to the right understanding of clapping.
\end{abstract}

\section{Keywords: clapping; applaus; worship; praise}

\section{Introduction}

Our worship experiences are marked by physical action. ${ }^{1}$ It covers dance and clapping, two medias of praise which have long been coloring the life of humankind. These activities are intended to express thanks, praise, admire, honor, and self glorification to a person or particular group who are considered as worthy to be honored. People of the Old Testament times do this to express honor to a particular people they admired, or to those who won the battle in the struggle of life, and to those who succeed in their life. The heathen expressed their praises to gods, while the people who know the living God do this for His glory.

Clapping has also been practiced during Christian era. The ultimate purpose of this celebration is to make God as the focus of worship, praise, glory and honor. True motive results in blessings, and when the motive of clapping is wrong then the blessings will not be obtained by the worshipers. Clapping or applause has been practiced by many people since ancient times

${ }^{1}$ Ronald Allan and Gordon Boror, Worship: Rediscovering the Missing Jewel (Portland, OR: Multnomah Press, 1982), 121. 
until the time of Christianity, whether it is intended for religious, secular, or social purposes. The Scripture gives many references about that. ${ }^{1}$

In Christianity, appalause has been a vital part of worship and adoration of the Christian churches. $^{2}$ Many of Christian denominations, including Seventh-day Adventist Church (SDA) give space for clapping or applause in worship services. Some feel uncomfortable when the congragation clap and dance while others, especially young people accept and enjoy it. ${ }^{3}$ Although many Christians agree, nevertheless, most of Christian denominations do not encourge clapping in the church services. ${ }^{4}$ Both groups have their own reasons why they accept or reject it. ${ }^{5}$ These two different understanding and views leave uncertainty and confusion within the minds of worshipers.

The purpose of this research is to identify whether the Scripture supports the practice of clapping in worship services as part of worship activities in the church or not. The second aim of the research is to descover the reason why some Christian denominations accept it while others reject this practice, some agree others strongly disagree. The third reason is to discover if there are theological recommendations to support the practice of applause in SDA worship service.

In this research, the words clapping and applause will be used changeably. It seems that these two words looked the same, however, as part of musical expression, clapping and applause are different. ${ }^{6}$

1. Clapping. Clapping is to hit the hands together repeatedly, quickly, and loudly to express approval. ${ }^{7}$ This word is also used to express pleasure. ${ }^{1}$

${ }^{1}$ W. David, "For the Beauty of the Church: Casting a Vision for the Arts", ed., in "Dance in Worship - What Does the Bible Say?" [On-line document]; Available from http://www.gotquestions.org/dance-in-worship.html; Internet; retrieved August 25, 2015.

${ }^{2}$ James F. White, Introduction to Christian Worship (Nashville: Abingdon, 1980), 103.

${ }^{3} J$. Stephen Lang, “1,001 Things You Always Wanted to Know About the Holy Spirit (Nashville: T. Nelson Publishers, 1999), 37, in Patrick Etoughé Anani, "Clapping: Fit or unfit for worship?.” Journal quarterly “Elder's Digest,” October/December 2011.

${ }^{4}$ Ibn Zura, "Why are Christians clapping, singing and dancing in church?” [document online]. Available from

http://www.ibnzura.com/answer.php?lang=en\&id=85002\&q=Why_are_Christians_clapping,_sin ging_and_dancing_in_church?; Internet; retrieved August 25, 2015.

${ }^{5}$ Todd Clippard, "Worship." [on-line document]. Available from http://www.housetohouse.com/BibleQuestions.aspx?Letter=all\&Question=4424; Internet; retrieved August 25, 2015.

${ }^{6}$ Evangelical Lutheran Church in America, "Is Applause Appropriate in Worship?" January 2013 [document on-line]. Available from www.elca.org/worshipfaq.). Internet; retrieved August 25, 2015.

7"'Clap.” Microsoft Encarta 2009. Electronic Dictionary, 1993-2008; Microsoft Corporation. 
2. Applause. Applause bears some purposes. The word is derived from Latin "applaudere," meaning to strike upon, clap. ${ }^{2}$ Further, the significance of this word is described in the following:

Applause is primarily expressed by clapping or striking the palms of the hands together to show appreciation via some degree of noise for whatever is being executed. Audiences are usually expected to applaud after a performance, such as a musical concert, speech, or play. The custom of clapping is perceived as an audience's nonverbal communication that could indicate its relative appreciation of a performance; the louder and longer the noise, the stronger the crowd's approval. ${ }^{3}$

Indonesian word is known as "aplaus" meaning "menepuk tangan secara serentak sebagai tanda setuju, pujian, atau simpati dalam rapat-rapat atau pertemuan, dan sebagainya atau kagum yang biasa terlihat dalam pertunjukan-pertunjukan; apresiasi, penghargaan, pujian, tepuk tangan [clapping together spontaneously as a sign of approval, for instance in meeting, or admiring which is usually seen in performances; appreciation, respect, and praise]. ${ }^{4}$ It is a sign of welcome, enjoyment, appreciation, or approval..$^{5}$ The transitive verb express approval, to praise somebody or something. ${ }^{6}$ It expresses praise or approval by stamping the feet, shouting, or other demonstration. ${ }^{7}$ Clapping is done purely with hands, applause is not just clapping, it can include cheering and stamping feet; Clapping is done by individuals and crowds, applause is more often done by a crowd. ${ }^{8}$

${ }^{1}$ Jean L. McKenchnie. Webters's New Universal Unabridged Dictionary. Deluxe, second ed. (New York: Dorset \& Baber, 1983), 333.

${ }^{2}$ Patrick Etoughé Anani, “Clapping: Fit or Unfit for Worship?” Journal Elder's Digest, October/December 2011, 8.

${ }^{3}$ Ibid.

${ }^{4}$ Departemen Pendidikan dan Kebudayaan, Kamus Besar Bahasa Indonesia. Jakarta: Balai Pustaka, 1990), 46.

5"Applause." Microsoft Encarta 2009. See also “applause” in http://www.thefreedictionary.com/applause.

${ }^{6}$ Ibid.

${ }^{7}$ Jean L. McKenchnie, op. cit., 89.

8"Applause," Online Dictionary: [On-line document]; Available from http://forum.wordreference.com/threads/clap-and-applaud.1006213/; Internet; retrieved September 10, 2015. 
Historically, the custom of clapping seems to walk hand-inhand with human history and conventions. It has been proved that clapping formed part of Egyptian culture and history. According to Herodotus (484-425 BC), Egyptians clapped their hands or used castanets and rattles during festivals in their processions as they traveled from town to town. ${ }^{1}$

According to Plutarch, the felicitas was a political phenomenon in which a popular audience was involved. He reports that Pompey envisioned entering the theater for its dedication while the people were clapping. ${ }^{2}$ At Corinth, citizens would greet Timoleon and show his preeminence by sending him on his way with shouting and clapping. ${ }^{3}$

The ancient Romans had a set ritual of applause for public performances, expressing degrees of approval: snapping the finger and thumb, clapping with the flat or hollow palm, or waving the flap of the toga, for which the emperor Aurelian substituted handkerchiefs (orarium) that he had distributed to the Roman people. ${ }^{4}$ According to Tacitus the historian, "it was their traditional custom to flatter any ruler with reckless

applause and meaningless zeal."5 The context of handclapping was games and theater, where spectators saluted the names of their heroes. ${ }^{6}$

There are four Hebrew words used in the Bible to express the movement of hands: saphak, nakah, macha', taqa' ${ }^{7}$

1. Saphak. Saphak, means menepuk (clap), memukul (hit), menampar (slap), menghukum (punish), mencemooh (mock). The example of saphak can be found in Job 27:23, 34:37; Lamentation $2: 15 .^{8}$

${ }^{1}$ Plutarch, Pompeius 46; at 68 (cf. Nicolaus of Damascus, Caes. 42); see, 169; Millar, Fergus "Popular Politics in the Late Republic," in Leaders and Masses in the Roman World: Studies in Honor of Zvi Yavetz, eds. J. Malkin and Z. W. Rubinsohn (Leiden: n.p., 1995), 106, in Patrick Etoughe Anani, “Clapping: Fit or Unfit for Worship? Journal Elder's Digest, October/December 2011, 9.

${ }^{2}$ Plutarch, ibid.

${ }^{3}$ Ibid.

${ }^{4}$ Böttiger, Über das Applaudieren im Theater bei den Alten, Leipz, 1822, in Patrick Etoughe Anani, “Clapping: Fit or Unfit for Worship? Jurnal Elder's Digest, October/December 2011, 9 .

${ }^{5}$ Tacitus, Historiae 1.32, 35, 90; 2.90, in Patrick Etoughe Anani, "Clapping: Fit or Unfit for Worship? Journal Elder's Digest, October/December 2011, 9.

${ }^{6}$ Tacitus, Ibid. 2.55, 91.

7'Ángel Manuel Rodríguez, "Clapping in the Church.” [On-line document]; Available from https://adventistbiblicalresearch.org/ materials/practical-christian-living/clapping-church; Internet; retrieved September 10, 2015.

${ }^{8}$ Mike \& Viv Hibbert, Pelayanan Musik (Yogyakarta: Penerbit Buku dan Majalah Rohani ANDI 1988), 152. 
The term saphak (clap one's hand) is combined with kaf in Numbers 24:10 as a sign of King Balak's strong disapproval of Balaam blessing Israel. The context seems

to indicate that the clapping of the pagan king was intended to prevent the prophet's speech. Called to curse Israel, not only did Balaam bless them (Num. 24:1-9a), he

also returned the curse against Moab, saying, "Blessed are those who bless you, and cursed are those who curse you" (verse 9b, ESV). The word saphak is also a sign of derision or mockery. In this context, it is used in association with shaqû (hiss) and yani' $\mathrm{u}$ (shake the head) (Lam. 2:15; cf. Job 27:23). ${ }^{1}$

2. Nakah. The meaning of verb "nakah" ranges from "memukul" (strike) to "membunuh" (kill). ${ }^{2}$ Hibbert specifies as follows: memukul, (striking), melukai (hurting), membunuh (killing), menghantam (fight, collide), mengadakan pembantaian (butchering)."3 Slapping someone's cheek is another meaning of "nakah." This word is found in Psalms 3:7, 8, and Lamentation 3:30. The same word is used in the inauguration of king such as in 2 Kings 11:12.

3. Makha. Makha means clapping as a sign of exaltation. ${ }^{5}$ Makha is mentioned in Psalms 98:8, "Let the floods clap their hands: let the hills be joyful together." The same word appears in Isaiah 55:12, "For ye shall go out with joy, and be led forth with peace: the mountains and the hills shall break forth before you into singing, and all the trees of the field shall clap their hands." The rushing river and the trees of the field clap the kaf and yad respectively in signs of joy when the prophet uses a personification of the trees (Is 55:12). It is "the rushing rivers recently filled from the thunderstorm which sounds like a grand audience clapping hands, and the rain-drenched mountains sing for joy" (98:8). ${ }^{6}$ When it is done as sign of joy or jubilation because of God's promises and everlasting deliverance, it is used with the word shâmach (joy). ${ }^{7}$ Ezekiel 25:6 says "For thus saith the Lord GOD; Because thou hast clapped thine hands, and stamped with the feet, and rejoiced in heart with all thy despite against the land of Israel; Clapped (mâcha) here is used as a sarcasm toward the Ammonites after they rejoiced over the fate of Israel by clapping their hands to indicate their scorn of the land of God's people and His sanctuary. It is coupled with the stamping of feet for merriment. ${ }^{8}$

${ }^{1}$ Ibid.

${ }^{2}$ Ibid

${ }^{3}$ Hibbert, 178.

${ }^{4}$ Ibid.

${ }^{5}$ Ibid.

${ }^{6}$ Anani, op. cit.

${ }^{7}$ Ibid.

${ }^{8}$ Ibid. 
4. Taqa'. Of all these four words, the term taqa' appears to be the most controversial, since it appears in Psalm 47:1 when the psalmist invites all people to clap their hands and "shout to God with loud songs of joy." The context seems to be eschatological, the idea appears on verses 5-8, although here it could designate an action of joy. In Nahum 3:19 the same term is used sarcastically at the downfall of Assyria.

\section{Methodology}

This research is done through the following phases: The first thing the researcher afforded is trying to formulate the problem. Following this step is describing the background of the study. Third step is determining the purpose of this research, and the fourth step is searching the supporting datas. Since this research is pure qualitative library research, all the datas needed are obtained by browsing materials provided in the library including printed materials and nonprinted materials such as electronic medias, etcetra. Beside this, the researcher spent time browsing the materials provided in the internet. After collecting the supporting matarials, the final step is focussing on discussin gand answering the problem, then followed by conclusion.

\section{Findings and Discussion}

Four Hebrew verbs are used to express the action of clapping (macha', nakah, saphak, taqa'), and all of them contain, as would be expected, the idea of striking something or someone. They are used in conjunction with the noun "hand" (Heb. kaf) to communicate the action of clapping ("striking the hands"). ${ }^{2}$ The phrase is used in several different ways ${ }^{3}$ :

1. It is an expression of joy at the ascension of the king. Psalms 47:1" O clap your hands, all ye people; shout unto God with the voice of triumph. This a social function of the gesture. Here the psalmist invites all peoples to clap their hands because the Lord is being proclaimed as King over the earth. When Joash was introduced as the legitimate heir to the throne those who were present clapped their hands and shouted, "Long live the king!" (2 Kgs. 11:2). In Ps 98:8 the people are exhorted to praise the Lord and the hills to clap their hands because the Lord is coming as King and Judge of the earth. Even nature should rejoice before the Lord. ${ }^{4}$ It is clear that there is no indication that clapping is done in worship service.

Many of the passages are figurative saying trees, rivers, or nations clap hands. In 2 Kings 11:12 there was a clap of the hands at the anointing of a king. This was not applause as we know it today and it was not an act of worship or used in connection with a spiritual event. ${ }^{5}$ Clapping

${ }^{1}$ Anani, op cit.

${ }^{2}$ Rodriquez, op cit.

${ }^{3}$ Ibid.

4"'Floods clap" (Psalms 98:8). The Seventh-day Adventist Bible Commentary (SDABC), rev. ed., ed. Francis D. Nichol (Washington, D.C.: Review and Herald Publishing Association, 1976-80), 3:854. 
mentioned in this text is body language as part of art which is performed in social activities, and there is no indication that this kind of praise is performed in sanctuary worship services.

2. The expression of joy because of God's action in saving people. Isaiah 55:12 informs, "For ye shall go out with joy, and be led forth with peace: the mountains and the hills shall break forth before you into singing, and all the trees of the field shall clap their hands." In this text the prophet Isaiah personified trees of the field to describe the joy of God's people. Indeed, this imagery is common in all poetry. This language is that which is properly applicable to the exiles in Babylon, but there can be no doubt that the prophet looks also to the future happier times of the Messiah. ${ }^{1}$

3. The expression of wrath, repugnant, abhorrent. Balak got angry when Balaam cursed the people of Israel. The wrath of Balak is expressed by striking or smiting his hands (Numbers 24:10). The Lord said Ezekiel to smite his hand, and stamp with his as a sign of abhorance (Ezekiel 6:11). The Lord showed His abhorence and anger to His people in a way of striking His hands (Ezekiel 22:13; 21:14, 17). His action is followed by punishment of sinners.

4. The expression of bad joy. This idea is found exclussively in in the context of defeated enemy. Nahum 3:19" There is no healing of thy bruise; thy wound is grievous: all that hear the bruit of thee shall clap the hands over thee: for upon whom hath not thy wickedness passed continually?" The Ammonites clapped their hands, stamped with the feet, and rejoiced before the people of Israel when they were destroyed by Babylon (Ezekiel 25:6). The abhorrent and enmity is also appear in Lamentation 2:15, "All that pass by clap their hands at thee; they hiss and wag their head at the daughter of Jerusalem, saying, Is this the city that men call the perfection of beauty, the joy of the whole earth?" It is clear that clapping in this context is not performed in worship service.

\section{The Christian and practice of clapping in worship services}

Some Chritian denominations say that clapping should be a part of praise in Christian worship, on the other hand many of Christian denomination members think that this practice should not be part of Christian worship. The reasons of these two different views are described in the following discussion.

1. The reason of acceptance. Clapping in worship service of Pentecostal churches is considered as a vital part of worship. In these modern times, with the rise in prominence of the charismatic Pentecostal style rites, ceremonies or expressions with their near $100 \%$ participation in clapping, they have demonstrated on some occasions wild body motions, whooping noises and whistling such as might be observed at a sporting event. ${ }^{2}$ To them clapping is a sign of God's

${ }^{5}$ Don R. Freiling, “Applause during Worship.” Truth Magazine. [On-line document]; Available form http://www.truthmagazine.com/archives/volume37/GOT037235.html; Internet; retrieved September 25, 2015.

${ }^{1}$ Barnes' Notes on the Bible. Available from http://biblehub.com/ commentaries/ Isaiah/55-12.htm; Internet; retrieved January20, 2016.

${ }^{2}$ Alvin Jennings, "Clapping: Another Form of Worship." [On-line document]. Available from http://www.scripturessay.com/clapping-another-form-of-worship/). Internet; retrieved September 10, 2015. 
people's expression of joy, and a form of exuberant joy of the worshipers worked by God in their hearts. ${ }^{1}$ They believe that God has instructed His people to clap hands and shout to God with songs of joy, for God has ascended amid shouts of joy, sounding of trumpets, and sing praises to God, to our King." (Psalm 47:1, 5-6). It is clear according to their conviction that the psalmist has instructed us that clapping can be worshipful because it is clapping in praise to God for something done in worship. ${ }^{2}$

2. The reason of rejection. The first reason of rejection is related to the acknowledment of man. Worship is the time to focus our mind to God, the moment to give honor and glory to God, and not to man, and all worship and praises should be addressed to God. Clapping is only for the glory and acknowledgement of man, and not to God. ${ }^{3}$ Hand clapping, whistling, and yelling are done at plays, ball games, the theater, and at other forms of entertainment to show our approval and satisfaction of the entertainment. This influence of the world has crept over into the church where people today want to clap during the worship or at a baptism, to show their approval of the "entertainment" they are receiving. We are not in the worship service to be entertained, but to give our worship to God. ${ }^{4}$ Jennings assures that it is nowhere in the Bible referred to as an act of praise, adoration or worship. Old Testament passages generally have reference to accounts of joyful celebrations as in war victories. In no place is it mentioned in connection with worship of any kind. The word "clap" does not appear at all in the New Testament, either as an act of worship or in any other connection or setting. ${ }^{5}$ Listiati said that in worship service the audience tends to applaud during or after musical presentation. To them clapping is one of appreciation forms. However, every time when worshipers applaud in worship service the essence of liturgy is totally lost and replaced by religious performance. ${ }^{6}$ Further

\section{${ }^{1}$ Pusat Studi Teologia, "PENGALAMAN ROHANI (Spiritual experiences) GERAKAN} PANTEKOSTA." 29 Mei 2009. [On-line document]; Available from http://pusatstuditheologiakatartizo.blogspot.co.id/ 2010/05/pengalaman-rohanispiritualexperiences.html; Internet; retrieved September 25, 2015.

${ }^{2}$ Alan Rudnick, "Is it wrong to clap in worship?" April 12, 2010. [On-line document]; Available from http://www.alanrudnick.org/ 2010/04/12/is-it-wrong-to-clap-in-worship/; Internet; retrieved September 25, 2015.

${ }^{3}$ Todd Clippard, op. cit.

${ }^{4}$ Ron Boatwright, "Hand Clapping in Worship?" [On-line document]; Available from http://www.netbiblestudy.net/bulletin/ new_page_80.htm; Internet; retrieved October 5, 2015.

${ }^{5}$ Jennings, Ibid.

${ }^{6}$ Ingrid Listiati, "Kenapa Tidak Ada Tarian, Sorak sorai dan Tepuk Tangan di Misa?" [On-line document]. Available from http://www.katolisitas.org/7422/kenapa-tidak-ada-tarian-sorak-sorai-dan-tepuk-tangan-di-misa. Internet; retrieved November 10, 2015. 
Mandang emphasized that applause can be done in musical concert at night, nevertheless, in worship service God should be our focus of adoration. ${ }^{1}$

The second reason is related to the Biblical facts. After doing his research on biblical clapping Sablett came up with his conclusion that there is no use of clapping in worship or praise in the Old Testament, ${ }^{2}$ nine scriptures in the Old Testament use the phrase (or a form of it) 'clap your hand' - not one authorizes the authority to do so in the worship service of the New Testament church. There are zero verses in the New Testament that even uses the phrase! ${ }^{3}$ Mandang suggested that instead of clapping, the best way the audience can do in responding the situation is just expressing gratitude to the performer with the honest words of thanks and appreciation after worship service, ${ }^{4}$ because there is no Bible texts supporting the practice of clapping, it means that God does not authorize clapping to become part of singing in worship place. ${ }^{5}$

\section{Clapping in Seventh-day Adventist Church}

Historically, according to the Seventh-day Adventist Church pioneers, The Adventist pioneers were aware of the fact that applause or other theatrical influences entered the early church when the early church accommodated the pagans in an effort to "win" them. Thus, E. J. Waggoner, one of the early Adventist pioneers referred to the effort of Chrysostom, Patriarchate of Constantinople, A.D. 398-404, in his opposition such worldliness in the church: "Chrysostom mourns over the theatrical customs, such as loud clapping in applause, which the Christians at Antioch and Constantinople brought with them into the church. ${ }^{6}$ In relation to the purpose of clapping in Seventh-day Adventist Church, Ellen G. White saw applause as a social expression of joy, appreciation, or approval. But she never recommended it for our worship services. For example, on one occasion in the $1880 \mathrm{~s}$, Sis. White was invited to speak at the Temperance

${ }^{1}$ Christina Mandang, "Peranan Utama Paduan Suara Di Dalam Ibadah.” [Online document]; Available from http://voiceofsoul.wordpress.com/2008/05/29/peranan-utama-paduansuara-di-dalam-ibadah/. Internet; retrieved November 10, 2015.

${ }^{2}$ Kenneth Sublett, "Hand Clapping in Worship Services.”[On-line document]. Available from http://www.piney.com/Clapp.html). Internet; retrieved October 5, 2015.

${ }^{3}$ Larry K. Rice, "No Clapping Hands in Worship.” June 13, 2014; [On-line document]; Available from http://kttradio.org/2014/06/13/ hand-clapping-in-worship-by-larry-k-rice/; Internet; retrieved October 5, 2015.

${ }^{4}$ Christina Mandang, "Peranan Utama Paduan Suara Di Dalam Ibadah" [On-line document]; Available from http://voiceofsoul.wordpress.com/2008/05/29/peranan-utama-paduansuara-di-dalam-ibadah/); Internet; retrieved November 10, 2015.

5"Kebenaran Bagi Dunia: Dua Ekspresi Pujian." [On-line document]; Available from http://kebenaranbagidunia.org/dua-ekpresi-pujian; Internet; retrieved November 10, 2015.

${ }^{6}$ Pipim, op. cit. 
Reform Club of Haverhill, Massachusetts, in a city auditorium seating one thousand people. She wrote concerning this experience: "I was stopped several times with clapping of hands and stomping of feet. ${ }^{1}$

John, Bishop of Rome in the fourth century, was also skeptical when he heard loud clapping during his homily. He rebuked it and said to the people, "The apostles, even Christ Himself delivering the Sermon on the Mount, have been listened to without interruption. Much better than noisy applause, the proper place for which was the theater or the public baths, was the secret approbation of the hearts as one reflects . . on the words spoken."2 James White also mentioned the "noise of shouting and clapping of hands" as one of the unwelcome behaviors that was associated with the Holiness Movement that threatened early Adventism at the Exeter camp meeting in New Hampshire. ${ }^{3}$

Theologically, applause has no real base in biblical tradition, it seem that churches that introduce this custom into worship are just following the entertainment industry or imitating the religious services of charismatic movements and churches. ${ }^{4}$

There is no evidence that clapping was a part of worship. For the Old Testament, clapping was social and cultural, not a religious practice. What we have in the churches today is nothing but a borrowed Greek and Roman "spectacle" heritage influenced by contemporary cultural norms, ${ }^{5}$ then Pentecostalism adopted this practice. This church has a unique style of worship and praise, and known for a distinctive style of praise and worship that is often spontaneous and exuberant. Clapping, singing, shouting, dancing, speaking in tongues and prophesying are all typical of Pentecostal worship services. ${ }^{6}$ The clapping members in SDA worship service is now increasing in its number. It is assured that many of SDA Church members have been influenced by Pentecostal way of worship which is not in accordance with the Biblical principles.

\section{${ }^{1}$ Ibid.}

${ }^{2}$ J.N.D. Kelly, "Golden Mouth: The Story of John Chrysostom: Ascetic, Preacher, Bishop," (New York: Cornell University Press, 1995), 130, 131. See in Gen. Sermo 2.1 (PG 54.586); in Act. Hom 30.4 (PG 60.266-7). Cf. J.P. Migne, ed., Patrologia graeca, 162 vols. (Paris, 185761886), dalam Patrick Etoughé Anani, “Clapping: Fit or unfit for worship?.” Journal Elder's Digest, October/December 2011, 10.

3ames White, "Life Incidents" (Battle Creek, MI: Steam Press of the Seventh-day Adventist Publishing Assn., 1868), 157. "Applause, Hand-waiving, drumming, and Dancing in the Church: Some Preliminary Reflections on Some Current Issues on Worship." [On-line document]; Available from www.drpipim.org; Internet; retrieved March 7, 2015.

${ }^{4}$ Patrick Etoughé Anani, op. cit., hal. 10.

${ }^{5}$ Ibid.

${ }^{6}$ Dell Markey, "Pentecostal Praise \& Worship," [On-line document]; Available from http://people.opposingviews.com/ pentecostal-praiseworship-2233.html; Internet; retrieved October 5, 2015. 


\section{The reason of clapping in Seventh-day Adventist Church}

Clapping during church services is becoming more and more popular in many of our churches. So your church is not unique in this respect. ${ }^{1}$ It seems that the church has given a space for clapping in the church services of Seventh-day Adventists Church. These phenomena have been fueled by several factors. Pipim enlists as follows: ${ }^{2}(1)$ the increasing worldliness in our churches, resulting in the adoption of Hollywood-style entertainment in our church services, (2) the adoption of the worship and evangelistic styles of popular mega-churches and Charismatic/Pentecostal churches of our day, (3) the attempt in developing countries to "indiginize" the church by incorporating elements from traditional, local, or non-Christian forms of worship, (4) a lack of understanding of what the Bible and Spirit of Prophecy says on the subject.

\section{The danger of clapping}

Ellen G. White (EGW) emphasizes applause as no more than just a social expression of joy, appreciation, or approval, and she never recommended it for our worship services. ${ }^{3}$ On one occasion in the 1880s, Sister White was invited to speak at the Temperance Reform Club of Haverhill, Massachusetts, in a city auditorium seating one thousand people. She wrote concerning this experience: "I was stopped several times with clapping of hands and stomping of feet." While she appreciated the enthusiasm of this non-Adventist audience, she never endorsed 'clapping and stomping of feet' as examples for Adventist worship services. ${ }^{5}$

Seventh-day Adventists understand that in the closing of the great controversy, worship is the issue. We have always known that the battle would rage around the day; now we know it will also include the way. Hand clapping, as innocuous as it appears to some, is letting the camel's nose of secular influence into the church. Shouting, whistling, and foot stomping have not yet arrived, but can they be far behind? Those who dare to touch the mountain will be tempted to touch the ark. ${ }^{6}$ EGW believed that applause was acceptable for Jesus'coming but not for

\footnotetext{
${ }^{1}$ Rodríguez. Op. cit.
}

${ }^{2}$ Samuel Koranteng-Pipim, “Applause, Hand-waiving, Drumming, and Dancing in the Church: Some Preliminary Reflections on Some Current Issues on Worship,” [On-line document]; Available from www.drpipim.org; Internet; retrieved March 7, 2015.

${ }^{3}$ Arthur L. White, Ellen G. White: The Lonely Years (Hagerstown, Md: Review and Herald, 1984), 46.

${ }^{4}$ Pipim. Op. cit.

${ }^{5}$ Ibid.

${ }^{6}$ Lee Roy Holmes. “And Now, a Round of Applause.” Adventist Affirm, A Publication Affirming Seventh-day Adventists Beliefs, Vol. 14, No.2; Summer 2000. [On-line document]; 
worship. She warned about its dangers as "the food of world" and one of "the iniquitous practices of the world. ${ }^{1}$

Moreover she emphasized that clapping is the food of the world, ${ }^{2}$ and a low standard. ${ }^{3}$ Further, Sister White warned applause as a snare, and something that can injure a person, ${ }^{4}$ stimulating like wine, ${ }^{5}$ and sure, it can injure a person. ${ }^{6}$ Applause will lead people to seek men's approval, where no man is safe, rather than the commendation of God. ${ }^{7}$ She reminded God's people who are living in the last days to be faithful, because only those who are faithful will be saved at last. ${ }^{8}$ Finally she warned that applause can influence someone to leave the church, ${ }^{9}$ and is poison that divides the church. ${ }^{10}$

\section{Amen An Alternative}

Waldroun found out that there is a great struggle going on in Christian churches between churches that practice traditional worship and those who have contemporary services. Some churches have contemporary services for the contemporary and traditional worship for the traditional. The traditionalists prize order, reverence, and solemnity, and their worship is thought

Available from http://www.adventistsaffirm.org/article/ 75/previous-issues/volume-14-number2/and-now-a-round-of-applause. Internet; retrieved August 25, 2015.

${ }^{1}$ Ellen G. White, Special Testimony to Ministers and Workers, No. 4, 1895, 25.

${ }^{2}$ White, The Southern Work. 1898, 1901 (Washington, D.C.: Review and Herald Publishing Association, 1966), 17.

${ }^{3}$ White, Patriarchs and Prophets. (Washington, D.C.: Review and Herald Publishing Association 1958), 650.

${ }^{4}$ White, Testimonies for the Church (Mountain View, CA: Pacific Press Publishing Association, 1948), 4:376.

${ }^{5}$ White, Testimonies for the Church (Mountain View, CA: Pacific Press Publishing Association, 1948), 3:185, 186.

${ }^{6}$ Ibid.

${ }^{7}$ White, The Ministry of Healing (Mountain View, CA: Pacific Press Publishing Association, 1942), 197.

${ }^{8}$ White, Testimonies for the Church (Mountain View, CA: Pacific Press Publishing Association, 1948), 2:102

${ }^{9}$ White, Review and Herald, June 28, 1897.

${ }^{10}$ Ibid. 
to be dead, lifeless, and formal by the contemporary. The contemporary prize joy, freedom, participation, and expression and their worship is seen as wild, irreverent, and even profane by the traditionalists. ${ }^{1}$ To overcome this conflict of understanding, he proposed to consider the saying of the amen during the corporate worship of the church. ${ }^{2}$

\section{Amen in Old Testament}

The Theological Wordbook of the Old Testament says: "The derivative 'men' "verily" is carried over into the New Testament in the word amen which is English word "amen." 3 Jesus used the word frequently (Mt 5:18, 26 etc.) to stress the certainty of a matter. The Hebrew and Greek forms come at the end of prayers and hymns of praise (Psa 41:13 [H 14]; Psa 106:48; 2 Tim 4:18; Rev 22:20 etc.). This indicates that the term so used in our prayers ought to express certainty and assurance in the Lord to whom we pray.... 'men'. Verily, truly, amen. (Generally, the same in ASV, RSV.) The word expresses a certain affirmation in response to what has been said. It is used after the pronouncement of solemn curses (Num 5:22; Deut 27:15ff; Neh 5:13; Jer 11:5) and after prayers and hymns of praise (1Chr 16:36; Neh 8:6; Psa 41:13 [H 14], etc.). ${ }^{4}$ Twice the term is used to describe the Lord (Isa 65:16), and once simply to approve the words of a man (1Kings 1:36). Finally, Jeremiah uses the term once sarcastically in response to the false prophets (Jer 28:6). ${ }^{5}$ The use of amen was very common in the ancient times. In Old Testament the word "Amen" is used for some purposes:

1. To agree. The "amen" meant, "Yes, we agree with your blessing! We join in your blessing! All that you have said of God's greatness we let it echo in our Amen. We say, "True, and firm and reliable is what you have said." (Psalms 72:19).

2. To confirm the validity of an oath and declare themselves ready to bear its consequences. Examples include the twelve oaths of Deuteronomy 27:15-26. By the word Amen the congregation is saying "Yes" to God, agreeing with the imprecation." 6

${ }^{1}$ Samuel E. Waldron, "Saying of the Amen, Clapping, and Hand-raising in Worship 2." February 23, 2015. [On-line document]. Available from http://www.cbtseminary.org/2015/02/amen-clapping-and-hand-raising-2/; Internet; retrieved June $5,2015$.

${ }^{2}$ Ibid.

3“'Saying of the Amen, Clappin, and Hand-raising in Worship." Ibid. In Indonesian Bible version, "Alkitab" published by Lembaga Alkitab Indonesia (Indonesian Bible Society), 1998, 339, the word Amen is derived from Hebrew, meaning "sungguh," (trully), "pasti," (surely) "benar" (right, true).

${ }^{4}$ Ibid.

${ }^{5}$ Op. cit.

${ }^{6}$ Ludwig Koehler and Walter Baumgartner, Lexicon in Veteris Testament Libros, $2^{\text {nd }}$ ed. (Leiden: E.J. Brill, 1958), 61, in Allen and Borror, 111. 
3. Amen in the Old Testament is in the context of praise. A splendid example is given in the covenant renewal under Ezra (Nehemiah 8:6). ${ }^{1}$ Anderson affirms that "Amen" is used after a baruch (praise) formula by the person speaking the formula (Ps 41:14; 72:19; 89:53) as well as all those who hear it (Ps 106:48; 1 Chron. 16:36; Neh. 8:6). This type of praise-formula has a standard structure and always begins with the word Baruch: translated as "Blessed/Praised be....." 2

4. A way of affirming blessings. Pipes explains that amen is the congregational way of affirming the leader's blessing. When great things are being spoken to God or about God in a public assembly, the fitting thing to do is to express agreement and affirmation (Psalms 106:48). ${ }^{3}$

\section{Amen in New Testament}

Both the antiphonal praises and the following "Amen" portrayed here were characteristic of early Christian worship. Pliny, writing less than two decades after John, records that in their worship services the Christians "sang in alternate verses a hymn to Christ, as to a god" (Letters X. 96; Loeb ed., vol. 2, p. 403). Describing the celebration of the Lord's Supper, Justin Martyr, writing in the $2^{\text {nd }}$ century, says that after the leader of the congregation had offered prayers and thanksgivings, "the people assent, saying Amen. ${ }^{4}$

There is a greatest praise sounding in heaven which is responded by the voice of "Amen" of the four beasts (Revelation 5:14). This is a declaration of heavenly creatures to support, to agree, and to confirm the heavenly music after super mega choir of the universe presenting the greatest praises for Jesus the slain Lamb of God. In a spectacular panorama the apostle John beheld all the angels stood round about the throne, and about the elders and the four beasts, and fell before the throne on their faces, and worshipped God, saying, Amen: Blessing, and glory, and wisdom, and thanksgiving, and honour, and power, and might, be unto our God for ever and ever. "Amen." (Revelation 7:9-12). The meaning of this word "Amen" in this beautiful and marvelous song of praise is "Yes" to God, and this is the reason why all Christians need to train themselves to say "Amen." The significant of "yes" is "agree" or "truly."

\section{${ }^{1}$ Allen and Borror, Ibid.}

${ }^{2}$ R. Dean Anderson, Jr. "Use of the Word Amen," extracted from Ordained Servant vol. 7, no. 4 (Oct. 1998), pp. 81-84. [On-line document]; Available from http://www.opc.org/OS/ html/V7/4d.html; Internet; retrieved June 5, 2015.

${ }^{3}$ John Piper, “Amen A Word Common to Many Languages," February 1, 1998. [On-line document]; Available from http://www.desiringgod.org/messages/amen; Internet; retrieved 5 June 5, 2015.

4"Amen" (Revelation 5:14), The Seventh-day Adventist Bible Commentary (SDABC), rev. ed., ed. Francis D. Nichol (Washington, D.C.: Review and Herald Publishing Association, 1976-80), 7:774.

${ }^{5}$ Allan dan Borror, 113. 
Since Amen is often used in the New Testament both by the speaker and the audience which aimed to confirm praise to the Lord, this must be used to substitute clapping. ${ }^{1}$ Saying amen is part of worship in Old Testament time (Deut. 27:15-26; 1 Chron. 16:36; Neh. 8:6; and Psalms 106:48). Amen was also used by Christians in apostolic era (1 Kor. 14:16), and part of of worship services and praises in heaven (Wah. 5:14; 7:12, and 19:4). For that reason, it is the corporate duty of the people of God to respond with vocal amens to all appropriate public expressions of praise petition and proclamation in the worship of God. ${ }^{2}$

God has prepared the word "Amen." God knows this about worship and preaching. That is why for 4,000 years he has made it simple for us: he has prepared a word. "Amen." There is no talk here about shouting or dominating or distracting. This is simply the call to make preaching and praying a corporate exultation in the supremacy of God. It is a call for authentic heartfelt expressions of "Yes" and "Amen. ${ }^{3}$

\section{Conclusion}

People clap, people applaud. Clapping and applause haves been part of human life in the ancient people, Old and New Testament times. It was done for various purposes, such as social and religous purposes. The Christian churches of this modern era have adopted this practice into church worships. Undeniable the same religious activity has also been seen in Seventh-day Adventist Church worship services. Some aggree, nevertheless most of church members reject this to become part of SDA worship. Those who reject have a biblical-base reason that clapping (or applause) as found in our churches today was not part of the worship service in the Old and New Testaments, ${ }^{4}$ and indeed, applause or clapping in church has a secular ambiance. Its historic venue was the theater, the sports arena, the social gathering---not in sacred worship service. Applause is most often understood as acknowledgment or acclamation of a performance, and indeed it is very closely linked to entertainment. This is why, until recently, Adventist churches never encouraged the practice. ${ }^{5}$

${ }^{6}$ Anton M. Moeliono, penyunting. Kamus Besar Bahasa Indonesia (Balai Pustaka, 1990), 1015.

${ }^{1}$ R. Dean Anderson, Jr. Op. cit.

${ }^{2}$ Samuel E. Waldron, op cit.

${ }^{3}$ John Piper, “Amen A Word Common to Many Languages,” February 1, 1998. Op cit.

${ }^{4}$ Pipim, "Applause in the Worship Service." [on-line document]; available from http://www.diggingfortruth.org/article/3044/prophecy/spirit-of-prophecy-section/selectedquotations-egw-3-250-phrases/phrase-applause-212/applause-in-the-worship-service; Internet; retrieved 5 June 2015.

${ }^{5}$ Pipim, “Applause, Hand-waiving, Drumming, \& Dancing in the Church: Some Preliminary Reflections on Some Current Issues on Worship.” Op.cit. 
Although clapping or applause is not recommended in the Bible, this religious practice has been a common view in worship service of Seventh-day Adventist Church. To substitute this practice the church members should be encouraged to say "Amen" in response to what has been said or the music just presented or being presented by the singer. Education is crucial, singers of all ages, instrumentalists and all musical leaders, must be reminded continually that their role in worship is to proclaim and praise God, not to entertain God's people in worship. Those who preach are proclaiming the Gospel, not entertaining. Worshipers, too, are to be reminded that they gather to worship, not to be entertained. ${ }^{1}$ Church leaders including pastors are responsible to remind and to educate church members that applauding in worship services is not necessary. These spiritual leaders need to instruct and guide the church members to the right understanding of clapping.

There is also special counsel for the ministers. They should not try to seek praise or self honor and glorification in a form of applause. While brought in contact with the world they should be on their guard that they do not seek too ardently for the applause of men and live for their opinion. ${ }^{2}$ They are also warned that ministers of ability who are now preaching present truth, love approbation. Applause stimulates them, as the glass of wine does the inebriate. Place these ministers where they have a small congregation which promises no special excitement and which provokes no decided opposition, and they will lose their interest and zeal, and appear as languid in the work as the inebriate when he is deprived of his dram. These men will fail to make real, practical laborers until they learn to labor without the excitement of applause. ${ }^{3}$

${ }^{1}$ Evangelical Lutheran Church in America (ELC). Ibid.

${ }^{2}$ White. Counsels on Health. (Mountain View, CA: Pacific Press Publishing Association, 1957), 384.

${ }^{3}$ White, Testimonies for the Church. (Mountain View, CA: Pacific Press Publishing Association, 1948), 3:185-186. 